Marzena Dobosz* (iD http://orcid.org/0000-0001-7027-0784

Uniwersytet Warmińsko-Mazurski w Olsztynie

https://doi.org/10.25312/2083-2923.18/2020_06md

\title{
Tożsamość regionalna i kulturowa współczesnej młodzieży - refleksje wokół roli edukacji regionalnej we współczesnym świecie
}

\begin{abstract}
Streszczenie: W coraz szybciej globalizującym się świecie, który przypomina „supermarket kultury", oferujący nietrwałe i wciąż zmieniające się wzorce kulturowe, młode osoby potrzebują wsparcia w kształtowaniu własnej tożsamości kulturowej. Dlatego edukacja regionalna, która ma wpływ na proces tworzenia się tożsamości regionalnej, będącej fundamentem tożsamości kulturowej, pozwala na stworzenie silnej identyfikacji i więzi $\mathrm{z}$ regionem. To z kolei może pomóc młodzieży w stworzeniu autokoncepcji i odnalezieniu własnego miejsca. W związku z tym edukacja regionalna jest drogą do budowania mikroświata przygotowującego do życia w makroświecie.
\end{abstract}

Słowa kluczowe: edukacja regionalna, tożsamość regionalna młodzieży, tożsamość kulturowa, globalizacja

\section{Wstęp}

Edukacja regionalna realizowana zarówno przez instytucje oświatowe, jak i pozaszkolne ma wpływ na proces kształtowania się poczucia tożsamości regionalnej młodych osób. To dzięki zróżnicowanym formom edukacyjnym i dydaktycznym o tematyce regionalnej istnieje możliwość poznania przez młodzież historii, kultury i tradycji, dziedzictwa kulturowego „małej Ojczyzny”, a także „zakorzenienia się w przestrzeni” wciąż zmieniającej się rzeczywistości. Dlatego poznanie symboliki

Marzena Dobosz - doktorantka na kierunku pedagogika na Wydziale Nauk Społecznych Uniwersytetu Warmińsko-Mazurskiego w Olsztynie. Współpracownik w Katedrze Wczesnej Edukacji. Zainteresowania naukowe: tożsamość kulturowa, edukacja regionalna, współczesna kultura, nowoczesne technologie w edukacji. 
i kultury regionalnej rozumianej zarówno w szerszym, jak i w węższym znaczeniu umożliwia tworzenie się więzi między młodym odbiorcą a wspólnotą regionalną, które stanowią istotny element tożsamości zarówno jednostkowej, jak i społecznościowej. Ponadto edukacja regionalna pomaga w dostrzeżeniu nie tylko wartości, czy też unikatowych cech danego regionu, ale także problemów dotykających lokalną społeczność. A to z kolei może zachęcić młode osoby do przyjęcia aktywnych postaw i inicjowania działań wobec zachowania, ochrony, a także pielęgnowania regionalności oraz jej bogactw.

\section{Zadania edukacji regionalnej w kształtowaniu tożsamości kulturowej}

Jednym z głównych zadań edukacji regionalnej jest przekazywanie wiedzy, uwrażliwianie, wspieranie i inicjowanie postaw oraz działań zmierzających do kształtowania więzi z regionem uznawanym i postrzeganym jako „mała Ojczyzna” lub „Ojczyzna prywatna”. Dzięki temu młody odbiorca jako uczestnik i uczeń zostaje wyposażony $\mathrm{w}$ ważną wiedzę, która $\mathrm{z}$ jednej strony chroni jednostkę przed poczuciem zagubienia się w dynamicznej i niestałej rzeczywistości, $\mathrm{z}$ drugiej zaś pozwala na prowadzenie dialogu oraz otwarcie na inne, obce lub dotąd nierozumiane wartości, poglądy i postawy. Ponadto edukacja regionalna umożliwia powrót do „korzeni”, do początków, które miały wpływ na obecny kształt i obraz regionu ujmowanego ze zróżnicowanych perspektyw. To również droga do zrozumienia przyczyn i skutków wydarzeń mających wpływ na współczesny obraz lokalnego społeczeństwa, a także możliwość poddania ich przez samą jednostkę własnej interpretacji i identyfikacji.

Kolejnym niezwykle istotnym aspektem edukacji regionalnej jest jej ukierunkowanie na pobudzanie aktywnych postaw i głębszych więzi między regionem a jej odbiorcą. Bycie obywatelem nie ma jedynie wymiaru ogólnego, ale przede wszystkim obejmuje postawy obywatelskie wobec regionu. To pierwsza „ojczyzna”, z którą styka się młody człowiek i wobec której przyjmuje określone postawy. W związku z tym edukacja regionalna jest drogą do budowania tożsamości narodowej na fundamencie tożsamości regionalnej, szczególnie że proces kształtowania więzi z regionem przyczynia się do stworzenia silnej relacji między młodym człowiekiem a jego „prywatną Ojczyzną”. Należy także podkreślić, że granice tej „prywatnej Ojczyzny” i jej wymiary w dużej mierze zależą od stopnia przywiązania jednostki do regionu. Zatem określenia „prywatna” lub „mała Ojczyzna” mogą nie tylko odnosić się do konkretnego

${ }^{1}$ J. Nikitorowicz, Edukacja regionalna jako podstawa kreowania społeczeństwa obywatelskiego, [w:] A. Cudowska (red.), Kierunki rozwoju edukacji w zmieniającej się przestrzeni społecznej. Księga Jubileuszowa dedykowana profesorowi doktorowi habilitowanemu Michałowi Balickiemu, Trans Humana Wydawnictwo Uniwersyteckie, Białystok 2011. 
terytorium, ale również do pewnych elementów, świadczących o unikatowości, różnorodności oraz wielowymiarowości kulturowej.

Warto zauważyć, że wśród zmian zachodzących w społeczeństwie, które wydają się, iż stoją wobec siebie w opozycji, jest regionalizacja oraz globalizacja. Wśród tych ruchów społecznych to regionalizm daje szansę i możliwość na ochronę, utrzymanie oraz odrodzenie kultury lokalnej i regionalnej, będącej skarbnicą wartości scalających społeczność i zapewniających poczucie niepowtarzalności oraz odrębności ${ }^{2}$ W dobie globalizacji, gdzie przestają istnieć granice, a wartości wykształcone i pielęgnowane przez społeczeństwa regionalne zastępowane są ujednoliconymi zasadami oraz regułami, to regionalizm pozwala na przechowywanie, pielęgnowanie oraz przekazywanie wartości wspólnoty kulturowej. Dzięki temu, że regionalizm jest związany z różnymi płaszczyznami codziennego życia i obejmuje elementy historyczne, kulturowe, etnograficzne, geograficzne lub ekonomiczne, to pozwala na odniesienie się do świadomości społeczności lokalnej oraz wykształconych przez nią systemów wartości ${ }^{3}$ To takie charakterystyczne dla regionalizmu elementy, jak: język, zwyczaje, obyczaje oraz sposób ujmowania rzeczywistości, sprawiają, że dana kultura lokalna jest niepowtarzalna i ma wpływ na proces kształtowania się tożsamości u młodych osób zarówno regionalnej, jak i kulturowej.

W związku z tym należy także podkreślić subiektywny i współczesny wymiar postrzegania oraz definiowania regionalizmu. Pojęcie to nie odnosi się jedynie do perspektywy społecznej/wspólnotowej, ale obejmuje swoim zasięgiem indywidualność interpretowaną jako wyraz więzi jednostki z określonym regionem. To dzięki nim można regionalizm ujmować także z perspektywy ideologicznej, wyrażającej się w aktywnych postawach i działaniach zarówno jednostki, jak i społeczności na rzecz zachowania odrębności regionalnej ${ }^{4}$. W związku z tym regionalizm można ujmować jako zjawisko poszukiwania przez jednostkę i zbiorowość terytorialną własnej tożsamości poprzez przyjmowanie postaw uwarunkowanych aspektami psychologicznymi, socjologicznymi lub ekonomicznymi. Dlatego pojęcie regionalizmu odnosi się do szczególnego rodzaju działalności, opierających się na kulturze regionu oraz uwzględniających potrzeby i oczekiwania danej społeczności rozumianej jako wspólnota ${ }^{5}$. To lokalne aspiracje, pragnienia oraz potrzeby społeczności nieraz stają się motywacją do podejmowania działań o charakterze społeczno-kulturowym, których celem jest ich zaspokojenie przez wspólnotę.

W związku z tym regionalizm może przybierać postać poczucia odrębności kulturowej, dążenia do zachowania i kultywowania wartości, a także zagwarantowania

${ }^{2}$ K. Leśniak-Moczuk, Regionalizm $w$ teorii i praktyce, „Nierówności Społeczne a Wzrost Gospodarczy" 2018, nr 54(2), s. 161.

3 Tamże, s. 161-162.

4 Tamże, s. 162.

${ }^{5}$ M. Mamrocka, Regionalizm w Polsce - tradycja i współczesność (wybrane zagadnienia), „Seminare" 2014, t. 35, s. 149-150. 
równych praw dla swojej odrębności ${ }^{6}$. Dzięki temu możliwe jest przyjmowanie postaw, których celem jest ochrona i rozwój wartości regionu, a szczególnie charakterystycznych elementów, takich jak: język, kultura, obyczaje, tradycja regionalna, a także systemów wartości i inicjatyw podejmowanych na płaszczyźnie ekonomicznej i gospodarczej. To dobro społeczności lokalnej i regionu jest jednym z najważniejszych przyczyn podejmowania tego typu działań, zmierzających do zaspokojenia zaistniałych potrzeb oraz oczekiwań wspólnoty. Dlatego regionalizm można ujmować w trzech kategoriach pojęciowych: jako aspekt obiektywnej rzeczywistości, jako działalność podejmowana na rzecz regionu, np. kultury regionalnej, a także jako aspekt umiejscowiony w sferze wewnętrznych odczuć człowieka ${ }^{7}$. To przez tworzenie więzi emocjonalnych $z$ regionem następuje jego połączenie z jednostką i wspieranie procesu kształtowania się poczucia tożsamości kulturowej, której jednym z fundamentów jest tożsamość regionalna.

Ponadto w przypadku inicjowania oraz wspierania regionalizmu i związanych z nim ruchów społecznych, działań oraz postaw duże znaczenie ma podmiot zarówno przekazujący, jak i przyjmujący dorobek kulturowy regionu ${ }^{8}$. To przekazanie i przyjęcie przez kolejne pokolenia dziedzictwa przodków, całej tej skarbnicy wiedzy, wartości i innych elementów świadczących o regionalnej kulturze ma decydujące znaczenie dla jej utrzymania i zachowania spójności. Jeżeli kolejne pokolenia uznają idee, wartości, postawy i wytwory dotychczasowej kultury regionalnej za ważne, warte ochrony i akceptowane, to następuje jej przejęcie przez spadkobierców. Jednakże należy podkreślić, że „dziedziczenie” dorobku kulturowego przez następne pokolenia nie oznacza jego przejęcia w niezmienionej formie. Kolejni spadkobiercy modyfikują, zmieniają oraz dostosowują otrzymane bogactwa kulturowe i wartości w taki sposób, aby były zgodne z obecną rzeczywistością, w której funkcjonuje wspólnota regionalna. Dzięki temu dziedzictwo kulturowe nie jest jedynie pamiątką i świadectwem przeszłości, ale jest łącznikiem między dawnym światem a tym obecnym. I ten dorobek, scheda po przodkach przejęta przez społeczność lokalną ma wpływ na proces kształtowania się tożsamości regionalnej i kulturowej młodych osób. A to z kolei pozwala członkom społeczności na określenie samych siebie i własnej pozycji w stosunku do zróżnicowanych płaszczyzn otaczającej ich rzeczywistości.

W związku z tym dziedzictwo kulturowe regionu może zostać poddane przez kolejne generacje kryteriom, które wyznaczane są przez przemiany zachodzące w społeczeństwie. To one tworzą nowe ramy kształtującej się tożsamości regionalnej, wytyczając jednocześnie granice „prywatnej Ojczyzny”, tej która może być najbliższa sercu. Dlatego dużą rolę w procesie kształtowania tożsamości regionalnej młodzieży mają zróżnicowane formy edukacji regionalnej, które przekazują wiedzę i wartości

${ }^{6}$ B. Jałowiecki, Regionalizm, [w:] H. Domański (red.), Encyklopedia socjologii, Oficyna Naukowa, Warszawa 2000.

${ }^{7}$ M. Mamrocka, Regionalizm w Polsce..., dz. cyt., s. 149.

${ }^{8}$ J. Nikitorowicz, Edukacja regionalna..., dz. cyt., s. 23-24. 
związane z regionem i jego kulturą, a także zachęcają młode pokolenia do poznania własnych korzeni. W związku z tym edukacja regionalna, przekazująca wiedzę o dziedzictwie kulturowym, systemach wartości oraz sposobie postrzegania rzeczywistości przez wspólnotę regionalną i jednostkę, jest drogą do kształtowania poczucia przynależności i identyfikacji jednostki z regionem oraz jego społecznością.

\section{Rola edukacji regionalnej we współczesnym świecie}

Celem edukacji regionalnej jest przekazywanie dziedzictwa kulturowego regionu, a także uświadomienie młodego pokolenia o jego wielowymiarowości oraz różnorodności kulturowej. Świadomość ta pozwala na obudzenie w młodych odbiorcach potrzeb związanych z zachowaniem ciągłości kulturowej regionu, z modyfikacją już istniejących elementów oraz z wprowadzaniem nowych elementów, które są istotne i ważne dla obecnych spadkobierców. Tego typu działania prowadzą do kształtowania w młodych osobach poczucia tożsamości regionalnej, co z kolei sprzyja inicjowaniu postaw regionalistycznych ukierunkowanych na wzmacnianie poczucia przynależności do określonego miejsca9 ${ }^{9}$. We współczesnej rzeczywistości, w której następuje unifikacja tożsamości kulturowej młodego pokolenia, to edukacja regionalna jest szansą na znalezienie własnego miejsca w świecie, w którym to gotowe globalne wzorce kulturowe zastępują te, które pozwalają na głębszy wgląd w samego siebie.

Dlatego edukacja regionalna jest szansą dla „globalnego nastolatka”, którego tożsamość kulturowa w znaczącym stopniu jest kształtowana nie przez wartości narodowe, państwowe i te systemy aksjologiczne, które zostały wykształcone przez społeczeństwa regionalne i przekazywane kolejnym pokoleniom, ale przez kulturę popularną oraz ideologię konsumpcji ${ }^{10}$. Współczesna młodzież kształtuje w sobie tożsamość kulturową, która nie posiada mocnego fundamentu poczucia przynależności, lecz jest otwarta na propozycje pochodzące zarówno ze zdobytych doświadczeń, jak i źródeł medialnych. To tożsamości kulturowe, które charakteryzują się chwilowością i pewną ułudą komplementarnej całości stworzonej z kruchych elementów kulturowych, będących wyznacznikiem własnego „ja" ${ }^{\prime 1}$. To również ciągły proces przyłączania i odrzucania tego, co w danej chwili jest akceptowane przez młode pokolenie, które z jednej strony dąży do indywidualizmu i chęci bycia „innym”, z drugiej zaś korzysta w tworzeniu własnej tożsamości kulturowej z ogólnych, unifikujących rozwiązań oraz wzorców kultury globalnej, które oferuje im współczesny, globalizujący się świat.

9 P. Petrykowski, Edukacja regionalna. Problemy podstawowe i otwarte, Wydawnictwo Naukowe Uniwersytetu Mikołaja Kopernika, Torun 2003.

${ }^{10}$ A. Suchocka, I. Królikowska, Kreowanie tożsamości kulturowej jako wyzwanie XXI wieku, „Colloquium Wydziału Nauk Humanistycznych i Społecznych” 2014, nr 4, s. 75.

${ }^{11}$ W. Burszta, M. Dudzikowa, Uczyć się od idola. O istotnym źródle wiedzy potocznej uczniów, [w:] M. Dudzikowa, M. Czerepaniak-Walczak (red.), Wychowanie, Gdańskie Wydawnictwo Psychologiczne, Gdańsk 2007. 
W związku z tym często poszukiwanie własnego miejsca i korzeni w rzeczywistości, w której to dominuje kultura typu insert oraz instant, jest postrzegane jako niepotrzebne i bez znaczenia. Jednakże wciąż zmieniające się strategie życiowe, wzorce kulturowe i panujące przekonanie, że własną tożsamość, również tę kulturową, można konstruować i rekonstruować w sposób wolny i dowolny, korzystając z szerokiego wyboru kulturowych ofert, sprawiają, że młody człowiek staje się konsumentem w świecie, który coraz bardziej przypomina supermarket ${ }^{12}$. Młody człowiek korzystający z możliwości tworzenia własnej tożsamości na zasadzie konstrukcji i rekonstrukcji staje się ciągłym poszukiwaczem własnego „ja” oraz sensu ludzkiej egzystencji. Dlatego też coraz częściej podkreśla się, że młode osoby rozpoczynające dorosłe życie przeżywają swoisty kryzys tożsamości na różnych płaszczyznach: od ciągłego kwestionowania i podawania w wątpliwość swojej dotychczasowej tożsamości kształtowanej w okresie dzieciństwa, aż po negowanie zastanego oraz proponowanego przez dorosłych świata i systemów wartości ${ }^{13}$. Realizację tego zadania nie ułatwia wieloznaczna oraz wciąż zmieniająca się rzeczywistość, w której to dominuje podejście o charakterze konsumpcyjnym i hedonistycznym. I choć wydaje się, że kreowanie własnej tożsamości kulturowej w obecnych czasach jest łatwiejsze, np. ze względu na szeroki wybór różnych wzorców kulturowych, które można w każdej chwili zaakceptować lub zmodyfikować, to jednak to zadanie jest trudne do realizacji, szczególnie dla młodych osób. Dlatego to edukacja regionalna młodzieży jest drogą do kształtowania tożsamości regionalnej, będącej fundamentem tożsamości kulturowej.

Pojęcie „tożsamości regionalnej” u młodych osób odnosi się do trwałej i kształtującej się autokoncepcji, która ma miejsce w przypadku ich silnej identyfikacji z systemami wartości i symbolami kultury wykształconej oraz charakterystycznej dla danej społeczności regionalnej ${ }^{14}$. Podwaliną tego typu tożsamości jest poczucie własnej podmiotowości oraz stworzenie obrazu samego siebie, na którego kształt ma wpływ to, co jest specyficzne dla danej społeczności regionalnej. Dlatego jednym z ważnym elementów tożsamości regionalnej młodzieży jest poczucie identyfikacji z regionem, zarówno w szerokim, jak i w wąskim znaczeniu, które również wynika nie tylko z samej przynależności, ale przede wszystkim opiera się na zaklasyfikowaniu własnej osoby do określonych kategorii społecznych.

Młode osoby szukają wzorców do naśladowania i identyfikowania się z poszczególnymi elementami regionu i kulturą regionalną, np. ze znaczącymi osobami w społecznościach lokalnych, organizacjami społeczno-kulturowymi, tradycjami regionalnymi, czy też jej historią, tworząc własną, zindywidualizowaną tożsamość regionalną.

${ }_{12}$ Z. Melosik, Edukacja, młodzież i kultura współczesna. Kilka uwag o teorii i praktyce pedagogicznej, „Chowanna” 2003, t. 1 (19), s. 20-21.

${ }^{13}$ S. Domagalska, Dylematy tożsamościowe młodzieży w sytuacji zmiany kulturowej - kryzys tożsamości?, „Forum Socjologiczne” 2011, nr 2, s. 242-243.

${ }_{14}$ A. Zellma, Kształtowanie tożsamości regionalnej młodzieży w toku interakcji katechetycznych, „Studia Warmińskie” 2002, nr 39, s. 421. 
Identyfikacja młodych osób $\mathrm{z}$ regionem oraz kształtowana tożsamość regionalna pozwala na znalezienie odpowiedzi na takie pytania: „Kim jestem?”, „Kim są inni?, „Dlaczego my?”, „Czym się różnię/różnimy od innych?” i „Jakie są moje korzenie?”, które są niezwykle kluczowe w przypadku tworzenia swojej autokoncepcji i obrazu samego siebie.

W związku z tym, aby pomóc młodym osobom w kreowaniu własnej tożsamości i tożsamości kulturowej w świecie, który przypomina „supermarket” z gotowymi, lecz płytkimi i nietrwałymi wzorcami kulturowymi, należy zadbać o odpowiednią edukację regionalną, której zadaniem jest również ochrona przed unifikacją kulturową. Dzięki temu młode osoby mają możliwość nie tylko poznania historii i kultury regionu, ale przede wszystkim nawiązania więzi kulturowych, co jest istotne w przypadku kształtowania się tożsamości kulturowej. I choć we współczesnym świecie korzystanie z tego „supermarketu kultury” nie jest już możliwością, ale koniecznością, to jednak oferuje ono również szeroką gamę środków, metod i rozwiązań umożliwiających odbudowę więzi i korzeni, a także może stać się drogą do integracji rozproszonych cząstek w całość, tworząc tożsamość kulturową młodego pokolenia ${ }^{15}$.

To poczucie przynależności oraz wykształcenie silnych więzi między młodzieżą a regionem sprawiają, że pojawia się samoświadomość pewnej odrębności w postaci przeżycia psychicznego o intencjonalnym charakterze. Młode osoby budują swoją tożsamość regionalną na fundamencie wspólnoty i kultury regionalnej, co również pozwala na umiejscowienie samego siebie w przestrzeni społecznej oraz identyfikację z określonymi rolami społecznymi. Okres dorastania i wchodzenia w świat dorosłych oznacza zazwyczaj eksperymentowanie, poszukiwanie oraz akceptowanie bądź odrzucanie zaoferowanych ról i systemów wartości. Dzięki temu młode osoby mogą podejmować działania i przyjmować aktywne postawy w środowiskach lokalnych, prowadzących do kształtowania wspólnoty regionalnej oraz jej integracji ${ }^{16}$. To dostrzeganie podobieństw oraz różnic między członkami społeczności, które mogą składać się ze zróżnicowanych wspólnot etnicznych i kulturowych, pozwala również na przyjęcie postawy opartej na dialogu kulturowym. Świadomość istnienia i dostrzeżenie odmienności kulturowej oraz poznanie i zrozumienie swojej najbliższej kultury jest drogą do wzajemnego zrozumienia, porozumienia oraz inicjowania współpracy na zróżnicowanych płaszczyznach codziennego życia. Dlatego to dzięki edukacji regionalnej młode osoby mogą wykorzystać swoje możliwości oraz nabyć odpowiednie kompetencje, doświadczenie i umiejętności, które są niezbędne w przypadku

${ }^{15}$ G. Mathews, Supermarket kultury, przeł. E. Klekot, Państwowy Instytut Wydawniczy, Warszawa 2005.

${ }^{16}$ A. Szczurek-Boruta, Identyfikacja i kształtowanie się tożsamości młodzieży - aspekty teoretyczne i przyczynki empiryczne, „Prace Naukowe Uniwersytetu Śląskiego w Katowicach” 2010, nr 2805, s. 394. 
kreowania własnej tożsamości, zarówno waspekcie osobowym, społecznym, jak i kulturowym ${ }^{17}$.

W procesie edukacji regionalnej współczesne pokolenia uczą się unikania tendencji etnocentrycznych, tworząc tożsamość otwartą oraz taką, która odnosi się nie tylko do najbliższej przestrzeni i otoczenia jednostki, ale również swoim zasięgiem obejmuje aspekty kulturowe ogólnonarodowe, czy też kontynentalne. To świadomość istnienia wartości regionu oraz ich wpływu na młode osoby decyduje o poczuciu swoistości oraz przynależności do „małej” czy też „prywatnej” Ojczyzny. W związku $\mathrm{z}$ tym istotną rolę $\mathrm{w}$ tym procesie mają działania edukacyjne, które swoimi treściami i formą przekazu wpływają na subiektywny oraz obiektywny obraz tego małego miejsca i rzeczywistości wspólnoty regionalnej.

Dlatego edukacja regionalna w swoim zamierzeniu nie powinna jedynie skupiać się na wybranych aspektach regionu, ale musi mieć charakter interdyscyplinarny, składający się z takich elementów, które pozwalają młodym osobom na tworzenie w zglobalizowanym makroświecie tożsamości kulturowej bazującej na mikroświecie, jakim jest region i wspólnota regionalna.

W związku z tym edukacja regionalna powinna dotyczyć mikroekologii, czyli wiedzy o lokalnym środowisku przyrodniczym i możliwościach ekorozwoju, mikrogeografii obejmującej wiedzę o lokalnej topografii, historii regionalnej, obejmującej lokalne wydarzenia, rozwiązania polityczne i osoby, które mają i miały wpływ na kształt kultury regionalnej, czy też socjologicznej wiedzy na temat społeczeństwa lokalnego i przeobrażeń, które w nim zachodziły ${ }^{18}$. Ponadto treści edukacji regionalnej powinny także dotyczyć charakterystycznych elementów kulturowych regionu, np. gwary i jej odmian, lokalnej literatury i dzieł artystycznych, czy też współczesnej kultury materialnej, składającej się z m.in. architektury i urbanistyki. Dzięki temu w młodych pokoleniach kształtuje się świadomość istnienia procesów tworzących kulturę regionu oraz zdarzeń budujących jej współczesny wizerunek i wpływających na lokalne społeczeństwo.

Ponadto w przypadku tworzenia się tożsamości regionalnej młodych osób należy pamiętać, że wśród istotnych elementów decydujących o jej kształcie niezwykle ważne są aspekty emocjonalne wyrażane w postaci przeżyć i aktów psychicznych osób żyjących na danym terenie. To poczucie odpowiedzialności społecznej za losy wspólnoty regionalnej oraz za dbanie, ochronę i wzbogacanie języka, historii oraz kultury regionu sprawiają, że młode jednostki zaczynają identyfikować się z regionem. I jedną z podstaw tej identyfikacji są silne więzi emocjonalne, które przyczyniają się do przyjęcia postaw gotowości inicjowania altruistycznych działań, służących dobru wspólnoty regionalnej, społeczności, czy też całego regionu.

${ }^{17}$ J. Nikitorowicz, Edukacja regionalna..., dz. cyt., s. 26.

${ }_{18}$ M.S. Szczepański, Ludzie bez ojczyzny prywatnej i edukacja regionalna, [w:] T. Lewowicki, B. Grabowski (red.), Społeczności pogranicza: wielokulturowość, edukacja, Uniwersytet Śląski, Cieszyn 1996. 
Fundament tożsamości regionalnej młodzieży tworzą trzy grupy wartości o charakterze symbolicznym. Pierwsza z nich obejmuje symboliczne środki komunikacji, zapewniające ciągłość kulturową społeczności regionalnej oraz mające charakter poznawczy. Do tej kategorii należą język i religia, oddziałujące na sposób funkcjonowania, postrzegania oraz kształtowania systemów wartości przez członków danej wspólnoty regionalnej. To język poprzez utrwalone w nim obrazy kulturowe danego regionu pozwala na rozpoznanie tożsamości wspólnotowej przez to, że nie tylko jest pojmowany w sposób „emblematyczny”, ale jako źródło i skarbnica wartości, które są tworzone oraz dziedziczone przez kolejne pokolenia ${ }^{19}$. W przypadku religii jako systemu wierzeń i obrzędów można mówić o jej integrującej, zespalającej społeczność lokalną roli, będącej także przestrzenią kulturową, mającą wpływ na kształt wspólnoty regionalnej i wyznawanych przez nią systemów wartości.

Kolejne grupy wartości symbolicznych dotyczą ekspresji wyrażających się w postawach i działaniach, które świadczą o stosunkach i przekonaniach wobec najbliższej wspólnoty, a także społecznych interesów. To dzięki identyfikowaniu się młodych osób z określonym systemem wartości, stworzonych przez wspólnotę lokalną, można stymulować proces kształtowania się tożsamości kulturowej oraz regionalnej młodzieży oraz zachęcać ją do podejmowania działań na rzecz lokalnego społeczeństwa. To wielopłaszczyznowa edukacja regionalna staje się drogą do wzbudzania w młodych osobach poczucia świadomości istnienia problemów dotykających region, a także pozwala na nabycie umiejętności skonstruowania potencjalnych rozwiązań korzystnych dla różnych stron. W związku z tym należy pamiętać, że to kolejne pokolenia będą tworzyć i kształtować społeczność regionalną, zaś ich silna identyfikacja z regionem, przejawiająca się na różnych poziomach codziennego życia, jest wyznacznikiem jej trwałości, integracji oraz przetrwania dziedzictwa kulturowego w globalizującym się świecie.

Ponadto edukacja, a szczególnie ta regionalna, spełnia jeszcze jedno ważne zadanie, jakim jest ochrona młodego pokolenia przed zagubieniem się w szybko toczącej się rzeczywistości, w której to posiadanie i konsumpcjonizm stają się nadrzędnymi wartościami, zaś człowiek w swojej istocie jest sprowadzany do roli przedmiotu i towaru. Dlatego w tym natłoku bodźców, informacji, wciąż zmieniających się elementów i wzorców kulturowych oraz odrzucaniu tego, co wartościowe, to edukacja regionalna broni młodzież przed alienacją, uprzedmiotowieniem, samotnością oraz poczuciem braku posiadania fundamentów tworzących tożsamość jednostki. W związku z tym edukacja regionalna otwiera przed młodą osobą mikroświat, na którym można budować i tworzyć makroświat, prowadząc przy tym edukację o zasięgu narodowym oraz państwowym ${ }^{20}$. To silne więzi z regionem i jego dziedzictwem kulturowym są

${ }^{19}$ J. Bartmiński, Językowy obraz świata jako podstawa tożsamości narodowej, [w:] T. Kostyrko, T. Zgółka (red.), Kultura a kręgi tożsamości, Silesia, Poznań-Wrocław 2000.

${ }^{20}$ J. Nikitorowicz, Edukacja regionalna na pograniczach, [w:] A.W. Brzezińska, A. Hulewska, J. Słomska (red.), Edukacja regionalna, Wydawnictwo Naukowe PWN, Warszawa 2006. 
podstawą do tworzenia więzi z państwem i narodem, zaś odrzucanie tego, co lokalne, regionalne, a więc swoich korzeni, prowadzi do poczucia zagubienia i alienacji we współczesnym świecie. I dlatego tak ważną funkcję pełni edukacja regionalna młodzieży, przygotowująca ją do życia zarówno w ojczyźnie prywatnej, narodowej, jak i w świecie ${ }^{21}$. A zrozumienie tego, co jest wartościowe, unikatowe, a zarazem wzbogacające ludzkie życie w kulturze i dziedzictwie kulturowym regionu staje się drogą do identyfikacji kolejnych pokoleń $\mathrm{z}$ regionalnością, narodowością oraz w końcu $\mathrm{z}$ samym sobą.

\section{Zakończenie}

Edukacja regionalna jest jedną z dróg, która może pomóc młodym osobom w kształtowaniu tożsamości regionalnej i kulturowej w świecie, w którym to dominują tendencje globalizacyjne oraz dehumanizujące siły. To przez przekazywanie i utrwalanie wiedzy o regionie, tradycjach, kulturze oraz wartościach wykształconych oraz podtrzymywanych przez wspólnotę lokalną istnieje możliwość stworzenia silnych więzi $\mathrm{z}$ regionem, a więc również identyfikacji z dziedzictwem kulturowym. Dzięki temu współczesna młodzież poznaje własne korzenie oraz rozwija w sobie poczucie przynależności, co jest niezwykle istotne w przypadku szybko zmieniającej się rzeczywistości, w której to porzuca się trwałość na rzecz chwili.

Ponadto edukacja regionalna broni jednostkę przed uprzedmiotowieniem oraz pozwala spojrzeć na swoje otoczenie, najbliższe środowisko z perspektywy wspólnoty kształtowanej przez określone czynniki i wpływy zewnętrzne oraz wewnętrzne. Poza tym ten rodzaj edukacji umożliwia przyjęcie postaw, które z jednej strony będą ukierunkowane na ochronę bogactw kulturowych regionu, z drugiej zaś otworzą się na poznanie innych wartości oraz odmiennych kultur. W związku z tym edukacja regionalna jest drogą do prowadzenia edukacji w mezostrukturach, budowania tożsamości regionalnej będącej podstawą tożsamości kulturowej, a także wejścia przez młodzież i jej funkcjonowania w makroświecie, przy jednoczesnym poznawaniu swoich korzeni i utrzymywaniu silnych więzi z mikroświatem, jakim jest jej mała Ojczyzna.

${ }^{21}$ B. Synak, Społeczno-kulturowe aspekty edukacji regionalnej, [w:] K. Marzec-Holka (red.), Społeczeństwo. Demokracja. Edukacja. Nowe wyzwania w pracy socjalnej, Wydawnictwo Uczelnianie Akademii Bydgoskiej im. Kazimierza Wielkiego, Bydgoszcz 2000. 


\section{Bibliografia}

Bartmiński J., Językowy obraz świata jako podstawa tożsamości narodowej, [w:] T. Kostyrko, T. Zgółka (red.), Kultura a kręgi tożsamości, Silesia, Poznań-Wrocław 2000.

Burszta W., Dudzikowa M., Uczyć się od idola. O istotnym źródle wiedzy potocznej uczniów, [w:] M. Dudzikowa, M. Czerepaniak-Walczak (red.), Wychowanie, Gdańskie Wydawnictwo Psychologiczne, Gdańsk 2007.

Domagalska S., Dylematy tożsamościowe młodzieży w sytuacji zmiany kulturowej kryzys tożsamości?, „Forum Socjologiczne” 2011, nr 2.

Jałowiecki B., Regionalizm, [w:] H. Domański (red.), Encyklopedia socjologii, Oficyna Naukowa, Warszawa 2000.

Leśniak-Moczuk K., Regionalizm w teorii i praktyce, „Nierówności Społeczne a Wzrost Gospodarczy” 2018, nr 54 (2).

Mamrocka M., Regionalizm w Polsce - tradycja i współczesność (wybrane zagadnienia), „Seminare” 2014, t. 35.

Mathews G., Supermarket kultury, przeł. E. Klekot, Państwowy Instytut Wydawniczy, Warszawa 2005.

Melosik Z., Edukacja, młodzież i kultura współczesna. Kilka uwag o teorii i praktyce pedagogicznej, „Chowanna” 2003, t. 1 (19).

Nikitorowicz J., Edukacja regionalna jako podstawa kreowania społeczeństwa obywatelskiego, [w:] A. Cudowska (red.), Kierunki rozwoju edukacji w zmieniajacej się przestrzeni społecznej. Ksiega Jubileuszowa dedykowana profesorowi doktorowi habilitowanemu Michałowi Balickiemu, Trans Humana Wydawnictwo Uniwersyteckie, Białystok 2011.

Nikitorowicz J., Edukacja regionalna na pograniczach, [w:] A.W. Brzezińska, A. Hulewska, J. Słomska (red.), Edukacja regionalna, Wydawnictwo Naukowe PWN, Warszawa 2006.

Petrykowski P., Edukacja regionalna. Problemy podstawowe i otwarte, Wydawnictwo Naukowe Uniwersytetu Mikołaja Kopernika, Toruń 2003.

Suchocka A., Królikowska I., Kreowanie tożsamości kulturowej jako wyzwanie XXI wieku, „Colloquium Wydziału Nauk Humanistycznych i Społecznych” 2014, nr 4.

Synak B., Społeczno-kulturowe aspekty edukacji regionalnej, [w:] K. Marzec-Holka (red.), Społeczeństwo. Demokracja. Edukacja. Nowe wyzwania w pracy socjalnej, Wydawnictwo Uczelnianie Akademii Bydgoskiej im. Kazimierza Wielkiego, Bydgoszcz 2000.

Szczepański M.S., Ludzie bez ojczyzny prywatnej i edukacja regionalna, [w:] T. Lewowicki, B. Grabowski (red.), Społeczności pogranicza: wielokulturowość, edukacja, Uniwersytet Śląski, Cieszyn 1996. 
Szczurek-Boruta A., Identyfikacja i kształtowanie się tożsamości młodzieży - aspekty teoretyczne i przyczynki empiryczne, „Prace Naukowe Uniwersytetu Śląskiego w Katowicach" 2010, nr 2805.

Zellma A., Kształtowanie tożsamości regionalnej młodzieży w toku interakcji katechetycznych, „Studia Warmińskie” 2002, nr 39.

\section{Regional and cultural identity of modern youth - reflections on the role of regional education in the modern world}

Abstract: In an increasingly rapidly globalising world, which resembles a 'supermarket of culture' offering fragile and ever-changing cultural patterns, young people need support in shaping their own cultural identities. Regional education influences the process of creating a regional identity, itself the foundation of cultural identity, allowing the formation of a strong identity and a bond with the region. This, in turn, can help young people to develop an idea of who they are and to find their place in the world Therefore, regional education is a way to build a micro-world that prepares for life in the macro-world.

Keywords: regional education, regional identity of youth, cultural identity, globalisation

\section{About the author:}

Marzena Dobosz - Ph.D. in the field of education, at the Faculty of Social Sciences of the University of Warmia and Mazury in Olsztyn. Associate in the Department of Early Education. Academic interests: cultural identity, regional education, contemporary culture, modern technologies in education. 